\title{
CORRESPONDENCE
}

\section{HYPOSTOMES OF GIRVAN TRILOBITES}

Sirs, - Since the publication of my paper on " Hypostomes of Some Girvan Trilobites " (Geol. Mag., 1943, pp. 56-65) Dr. C. J. Stubblefield has kindly drawn my attention to a paper by Dr. F. B. Phleger, entitled "Further Notes on the Lichadacea" (Journ. Paleont., 1937, pp. 253-6), which I particularly regret having overlooked, since it deals with the backward extension of the hypostome in certain trilobites, a feature to which I drew attention in my paper. Dr. Phleger was able to develop these views regarding the anatomy of the mouth region (already indicated in an earlier paper, Journ. Paleont., 1936, pp. 593-615) after a visit to Britain during which he saw a number of specimens with large hypostomes. These included some examples in my own collection which he described, including one which had been figured previously by Dr. F. R. C. Reed (Girvan Trilobites, Supplement 3, Paleont. Soc., 1935). It may be useful to point out that the specimens of Platylichas crescenticus described by Phleger (1937, p. 254) as BG. 2080, 2080a, and 2082 are parts of the same individual. Phleger was aware that this was so in the case of BG. 2082 and 2080, but apparently not concerning the part which he recorded as BG. 2080a. The "impression of the upper surface" of the cephalon figured by Reed (op. cit., pl. iii, fig. 16) is numbered BG. 2082. The internal cast of the cranidium Reed figured in his plate iii, fig. 13, and the opposite side of this fragment, which shows the ventral view of the hypostome cast, in plate iii, fig. 15. But whereas this latter fragment is recorded as BG. 2082 by Reed, it was referred to by Phleger as BG. 2080a. Another fragment, BG. 2080, "the impression of the lower surface" of the cephalon, which also shows the impression of the hypostome, is illustrated in Reed's pl. iii, fig. 14. Phleger's suggestion (1937, p. 254) that the hypostomes in BG. 2080 and BG. 2080 $a$ are of different length thus arises from a misunderstanding, since they are positive and negative faces of the same individual.

J. L. BEGG.

Glasgow.

16th June, 1943.

\section{ACKNOWLEDGMENT}

The cost of the blocks illustrating Dr. Currie's paper on Promicroceras (Geol. Mag., lxxx, 1943, No. 1) was in part defrayed by a grant from the Carnegie Trust. 